\title{
Everolimus downregulates estrogen receptor and induces autophagy in aromatase inhibitor-resistant breast cancer cells
}

Asona Lui ${ }^{1,5}$, Jacob New ${ }^{2,5}$, Joshua Ogony ${ }^{3,5}$, Sufi Thomas ${ }^{2,3,4,5}$ and Joan Lewis-Wambi ${ }^{3,5^{*}}$

\begin{abstract}
Background: mTOR inhibition of aromatase inhibitor (Al)-resistant breast cancer is currently under evaluation in the clinic. Everolimus/RAD001 (Afinitor ${ }^{\circledast}$ ) has had limited efficacy as a solo agent but is projected to become part of combination therapy for Al-resistant breast cancer. This study was conducted to investigate the anti-proliferative and resistance mechanisms of everolimus in Al-resistant breast cancer cells.

Methods: In this study we utilized two Al-resistant breast cancer cell lines, MCF-7:5C and MCF-7:2A, which were clonally derived from estrogen receptor positive (ER+) MCF-7 breast cancer cells following long-term estrogen deprivation. Cell viability assay, colony formation assay, cell cycle analysis and soft agar anchorage-independent growth assay were used to determine the efficacy of everolimus in inhibiting the proliferation and tumor forming potential of MCF-7, MCF-7:5C, MCF-7:2A and MCF10A cells. Confocal microscopy and transmission electron microscopy were used to evaluate LC3-II production and autophagosome formation, while ERE-luciferase reporter, Western blot, and RT-PCR analyses were used to assess ER expression and transcriptional activity.

Results: Everolimus inhibited the proliferation of MCF-7:5C and MCF-7:2A cells with relatively equal efficiency to parental MCF-7 breast cancer cells. The inhibitory effect of everolimus was due to G1 arrest as a result of downregulation of cyclin D1 and p21. Everolimus also dramatically reduced estrogen receptor (ER) expression (mRNA and protein) and transcriptional activity in addition to the ER chaperone, heat shock protein 90 protein (HSP90). Everolimus restored 4-hydroxy-tamoxifen (4OHT) sensitivity in MCF-7:5C cells and enhanced 4OHT sensitivity in MCF-7 and MCF-7:2A cells. Notably, we found that autophagy is one method of everolimus insensitivity in MCF-7 breast cancer cell lines.
\end{abstract}

Conclusion: This study provides additional insight into the mechanism(s) of action of everolimus that can be used to enhance the utility of mTOR inhibitors as part of combination therapy for Al-resistant breast cancer.

Keywords: Breast cancer, Aromatase inhibitor, RAD001, Everolimus, PI3K/Akt/mTOR, Estrogen receptor, Autophagy

\footnotetext{
* Correspondence: jlewis-wambi@kumc.edu

${ }^{3}$ Department of Cancer Biology, University of Kansas Medical Center, Kansas

City, KS 66160, USA

${ }^{5}$ The University of Kansas Cancer Center, Kansas City, KS 66160, USA

Full list of author information is available at the end of the article
} 


\section{Background}

Estrogen deprivation using aromatase inhibitors (AIs) is currently the standard of care for patients with estrogen receptor-positive $(\mathrm{ER}+)$ breast cancer. Unfortunately, $\sim 30 \%$ of breast cancer patients develop resistance to AIs following long-term treatment [1]. The mechanism by which AI resistance develops is still not completely understood, however, several contributing factors have been identified including; alterations in ER signaling, enhanced growth factor signaling, and imbalance in the phosphoinositide 3-kinase/protein kinase B/mammalian target of rapamycin (PI3K/Akt/mTOR) pathway $[2,3]$. The activation of the PI3K/Akt/mTOR pathway is considered clinically relevant for tumor escape from hormone dependence in breast cancer, promoting the survival of breast cancer cells in estrogen-deprived conditions [4]. Additionally, upregulation of the PI3K/Akt/mTOR pathway is associated with poor outcome for breast cancer patients and has been observed in AI-resistant breast cancer models $[5,6]$. As a result, a variety of PI3K/Akt/ mTOR pathway inhibitors have been under study, including everolimus/RAD001 (Afinitor ${ }^{\bullet}$ ).

Everolimus is a rapamycin analog that is currently approved for treatment of metastatic breast cancer. It inhibits the PI3K/Akt/mTOR signaling pathway by preventing the phosphorylation of $\mathrm{mTORC1}$, which interrupts the signaling cascade and results in inhibition of cell proliferation and growth [7]. Everolimus treatment has shown promising anti-cancer effects in preclinical studies; however, when used as a single agent, it does not significantly decrease tumor size [8]. As a result, recent clinical trials have focused instead on simultaneous targeting of the PI3K/AKT/mTOR and ER pathways in $\mathrm{ER}+$ breast cancer [9-11]. The results from these trials have been very encouraging due to significant improvements in response rate and progression free survival for both AI-sensitive and AI-resistant patients [12-14]. Subsequent laboratory studies have focused on comparison of everolimus in combination with endocrine therapies $[15,16]$ as well as other PI3K/Akt/mTOR inhibitors in a variety of breast cancer cell lines $[17,18]$ and these studies have reported synergy between tamoxifen or AI therapy and everolimus. However, these studies have not investigated the anti-cancer mechanisms of everolimus alone in AI-resistant breast cancer cells.

Everolimus and other PI3K/Akt/mTOR inhibitors are known to induce autophagy in both solid and blood tumors $[19,20]$; however, to our knowledge, the phenomenon has not been reported in breast cancer. Autophagy allows cells to degrade dysfunctional organelles and proteins, and recycle their components. Autophagy can support tumor survival during treatment, making it a possible mechanism for AI-resistance [21, 22]. This process is dependent upon the cleavage of microtubule associated light chain 3 (LC3) to
LC3-I and subsequent lipidation to LC3-II which allows for final formation of the autophagosome membrane [23]. A group of small proteins, called heat shock proteins (HSPs), promote cell survival during stress reactions by promoting the refolding of denatured proteins and directly regulating autophagy. Specifically, HSP70 is thought to be required for the induction of autophagy [24, 25] in response to inhibition of the PI3K/Akt/mTOR pathway by either starvation or rapamycin treatment $[26,27]$. Another heat shock protein, HSP27, allows cells to survive a variety of cytotoxic stimuli $[28,29]$ and is thought to be degraded during starvation and rapamycin-induced autophagy [30]. Due to the link between drug resistance and autophagy, we hypothesized that the induction of autophagy may contribute to everolimus insensitivity in MCF-7 breast cancer cell lines.

In this study, we investigated the effects of everolimus, as a single agent, or in combination with 4-hydroxy tamoxifen (4-OHT) or chloroquine on cell proliferation, anchorageindependent growth, PI3K/Akt/mTOR signaling, ER expression and transcriptional activity, LC3 turnover, and autophagosome induction in AI-sensitive MCF-7 and AIresistant MCF-7:5C and MCF-7:2A breast cancer cells. We report that everolimus exerts similar anti-proliferative effects in both the AI-sensitive and AI-resistant breast cancer cell lines and that its inhibitory activity is associated with G1 arrest and down regulation of ER $\alpha$ expression. Everolimus also reverses and enhances $4 \mathrm{OHT}$ sensitivity during long-term co-treatment of the AI-resistant cell lines. Lastly, we report that autophagy is a mechanism of everolimus insensitivity in MCF-7, MCF-7:5C and MCF-7:2A cells, possibly explaining the equal response of these cell lines to treatment. The information from this study may enhance future selection of everolimus containing combination therapies for AI-resistant breast cancer.

\section{Methods}

\section{Cell lines and culture conditions}

The MCF-7 cell line [31, 32] was obtained from Dr. V. Craig Jordan (University of Texas MD Anderson Cancer Center, Houston) and maintained in RPMI-1640 medium supplemented with $10 \%$ fetal bovine serum, $2 \mathrm{mM}$ glutamine, Antibiotic/Antimitotic mix, MEM Non-Essential Amino Acids (Invitrogen, Waltham, MA), and bovine insulin at $6 \mathrm{ng} / \mathrm{mL}$ (Sigma Aldrich, St. Louis, MO). The long-term estrogen deprived human breast cancer cell lines; MCF-7:5C [31, 33] and MCF-7:2A [32, 34] were cloned from parental MCF-7 cells following long term (>12 months) culture in estrogen-free medium composed of phenol red-free RPMI-1640, $10 \%$ fetal bovine serum treated three times with dextran-coated charcoal (SFS), $2 \mathrm{mM}$ glutamine, bovine insulin at $6 \mathrm{ng} / \mathrm{mL}$, Antibiotic/ Antimitotic mix, and MEM Non-Essential Amino Acids (Invitrogen). The MCF10A cell line was purchased from the American Type Tissue Culture Collection. They are 
maintained in Dulbecco's Modified Eagle Medium: Nutrient Mixture F-12 (DMEM/F12) in a 1:1 mixture and supplemented with $5 \%$ horse serum, Antibiotic/Antimitotic mix $(100 \mathrm{IU} / \mathrm{mL}$ penicillin, $100 \mu \mathrm{g} / \mathrm{mL}$ streptomycin, $25 \mu \mathrm{g} / \mathrm{mL}$ of Fungizone ${ }^{\oplus}$ from Invitrogen, Grand Island, $\mathrm{NY}$ ), $20 \mathrm{ng} / \mathrm{ml}$ EGF (Millipore), $0.5 \mathrm{mg} / \mathrm{ml}$ hydrocortisone, $100 \mathrm{ng} / \mathrm{ml}$ cholera toxin (Sigma Aldrich). All cell lines were cultured at $37{ }^{\circ} \mathrm{C}$ under $5 \% \mathrm{CO}_{2}$. After overnight acclimatization period, cells were cultured with $20 \mathrm{nM}$ everolimus alone or in combination with $1 \mu \mathrm{M}$ 4-hydroxytamoxifen (Sigma Aldrich) or $50 \mu \mathrm{M}$ Chloroquine (InvivoGen, San Diego, CA), in their normal culture medium.

\section{Cell viability}

Cells were assayed for viability in 24-well plates using the Cell-Titer Blue Assay Kit (Promega, Madison, WI) per the manufacturer's instructions. Assay plates were kept at $37{ }^{\circ} \mathrm{C}$ in $5 \% \mathrm{CO}_{2}$ for $3 \mathrm{~h}$ and read at 560-590 nM on a BioTek Synergy 4 microplate reader using the Gen 5 data analysis software (BioTek Instruments, Winooski, VT).

\section{Western blotting}

Cells were seeded in 6-well plates, collected using a cell scraper and suspended in RIPA buffer (Thermo Scientific, Pittsburgh, PA) supplemented with protease inhibitor cocktail and phosphatase inhibitor (Sigma Aldrich). Cells were homogenized over ice by sonication. After purification of the sample by centrifugation, protein concentration was determined by protein assay (Bio-Rad, Hercules, CA). The proteins were separated by 4-12\% SDS-polyacrylamide gel electrophoresis (SDS-PAGE) and electrically transferred to a polyvinylidene difluoride membrane (Santa Cruz Biotechnology). After blocking the membrane using $5 \%$ non-fat milk, target proteins were detected using either Anti-mTOR, anti-phosphomTOR, anti- LC3A/B (Cell Signaling, Beverly, MA), anti-p70S6K, anti-phospho-p70S6K, anti-AKT, antiphospho-AKT (S473) or anti-ER $\alpha$ (Santa Cruz Biotechnology) antibodies. Membranes were stripped and re-probed for $\beta$-actin (Cell Signaling) or $\beta$-tubulin (Sigma Aldrich). The appropriate horseradish peroxidase (HRP)-conjugated secondary antibody was applied and the positive bands were detected using Amersham ECL Plus Western blotting detection reagents (GE Health care, Piscataway, NJ). In the case of LC3 analysis, cells were treated with $50 \mu \mathrm{M}$ chloroquine (CQ) for 24 or $48 \mathrm{~h}$ to allow for LC3-II accumulation. Immunoreactivity was detected using antimouse or anti-rabbit IgG conjugated to Dylight 680 or 800 fluorochromes (Thermo Scientific, Waltham, MA), respectively. Blots were visualized on Odyssey imager (LiCor, Lincoln, NE). Quantitation of immunoreactive signals was done by densitometry using ImageJ $1.46 \mathrm{r}$ software (NIH, Bethesda, MA). The ratio of protein expression to $\beta$-tubulin in each lane was calculated and presented relative to the respective controls within each experiment.

\section{Cell cycle analysis}

Cells were incubated in the appropriate cell culture media with and without drug treatment. Cells were harvested at the indicated time points by trypsinization. They were washed once with cold PBS and stained with $50 \mu \mathrm{g} / \mathrm{mL}$ Propidium Iodide and $100 \mu \mathrm{g} / \mathrm{mL}$ RNase A in PBS (Invitrogen). Samples were analyzed using a BD FACSAria ${ }^{\mathrm{Tm}}$ II Flow Cytometer (BD, Franklin Lakes, NJ) and the data were analyzed with FlowJo software (Ashland, OR).

\section{Clonogenic proliferation assay}

Cells were seeded at 1,000 cells per well in 6-well plate in singe cell suspension. After $24 \mathrm{~h}$ acclimatization, they were treated every three days and allowed to proliferate and establish colonies for 9 days. Cells were stained with $0.5 \%$ crystal violet in 1:7 acetic acid: methanol and imaged at $1 \mathrm{X}$ in a Bio-Rad ChemiDoc ${ }^{\mathrm{TM}} \mathrm{XRS}+$ System with Image Lab ${ }^{\mathrm{Tm}}$ Software (Bio-Rad Laboratories Inc., Hercules, CA). Colonies were counted and measured using Image J software (The National Institute of Health, Bethesda, MD).

\section{Soft agar anchorage-independent growth assay}

6-well plates were coated with $1 \mathrm{~mL}$ of $0.8 \%$ agarose in the appropriate culture media. Cells were then suspended in $0.48 \%$ agarose and immediately overlaid on the pre-coated plates. Once the agarose was solid, $1 \mathrm{~mL}$ of culture medium with or without $20 \mathrm{nM}$ everolimus was added and replaced every 4 days for 15 days. Cultures were then stained with $0.005 \%$ crystal violet in PBS, washed with PBS until the background was clear and imaged microscopically at 10X for measurement of colony diameter. Plates were also imaged at $1 \mathrm{X}$ in a BioRad ChemiDoc ${ }^{\mathrm{TM}} \mathrm{XRS}+$ System with Image $\mathrm{Lab}^{\mathrm{TM}}$ Software (Bio-Rad). Colonies were counted and measured using Image J software (NIH).

\section{Real time PCR}

Cells were seeded in 6-well plates and allowed to acclimatize overnight. Following 72 h treatment with 20 $\mathrm{nM}$ everolimus, cells were harvested by cell scraping in RLT lysis buffer and total RNA was isolated using the Qiagen RNeasy kit (Venlo, Limburg). First strand cDNA synthesis was performed from $3 \mu \mathrm{g}$ total RNA using MulV Reverse Transcriptase (Applied Biosystems, Carlsbad, CA) on a Bio Rad MyCycler ${ }^{\mathrm{Tm}}$. RT-PCR was conducted using the ViiA $^{\text {тm }} 7$ Real-Time PCR system (Applied Biosystems) and SYBR Green Reagent (Life Technologies, Carlsbad, CA) with primers specific for ER $\alpha$ and the housekeeping 
gene PUM1. Primers for ER $\alpha$ : Forward 5'-AAGAG GGTGCCAGGCTTTGT-3', Reverse 5'-CAGGATCTC TAG CCAGGCACAT -3'. Primers for PUM1: ForwardTCACCGAGGCCCCTCTGAACCCTA Reverse- GGCA GTAATCTCCTTCTGCATCCT (Integrated DNA Technologies, Coralville, Iowa). Relative ER $\alpha$ mRNA expression level was determined as the ratio of the signal intensity to that of PUM1 using the formula: $2^{-\Delta C T}$. When treated with everolimus, fold change in ER $\alpha$ expression was normalized to PUM1 and then compared to the untreated value for that cell line using the formula: $2^{-\Delta \Delta C T}$.

\section{Luciferase reporter assay}

Cells were seeded in 12-well tissue culture plates overnight for attachment before transfection. The cells were transfected using Lipofectamine $2000^{\mathrm{Tm}}$ Transfection Reagent (Invitrogen, San Diego) according to the manufacturer's recommendations. Briefly, $4 \mu \mathrm{L}$ of Lipofectamine 2000, $0.8 \mu \mathrm{g}$ of ERE Luciferase plasmid DNA and $0.01 \mu \mathrm{g}$ of the pRL CMV Renilla (Promega) were diluted individually in 250- $\mu$ l aliquots of OptiMEM ReducedSerum Medium (Invitrogen). Cells were incubated for $24 \mathrm{~h}$ after transfection, and then treated with $20 \mathrm{nM}$ EVE or vehicle in complete media for $24 \mathrm{~h}$. The Luciferase and Renilla activities were measured using the dual luciferase assay kit (Promega) according to the manufacturer's instructions. To confirm the specificity of the ERE Luciferase construct, EVE treated cells were also compared to those treated with $1 \mathrm{nM} 17 \beta$-estradiol and 1nM Fulvestrant, a pure anti-estrogen (Sigma). Relative Fluorescence Units (RFUs) were calculated as a ratio of Luciferase to Renilla signal intensity. The ERE Luciferase reporter construct was a kind gift from Dr. Clodia Osipo (Loyola University, Chicago, IL).

\section{Immunofluorescence microscopy}

Cells grown on glass coverslips were washed in PBS and fixed with $100 \%$ ice cold methanol for $10 \mathrm{~min}$. After permeabilization by $0.1 \%$ Triton $\mathrm{X}-100$ in PBS for $10 \mathrm{~min}$, cells were incubated with $5 \%$ normal horse serum/PBS for $30 \mathrm{~min}$, followed by incubation with ER $\alpha$ or LC3B antibody, $2 \mu \mathrm{g} / \mathrm{mL}$ in $0.01 \%$ Triton X-100 /PBS overnight (Santa Cruz Biotechnology). Cells were stained with fluorescein isothiocyanate (FITC)-conjugated labeled goat anti-rabbit IgG (Cell Signaling), $4 \mu \mathrm{g} / \mathrm{mL}$ in PBS for $1 \mathrm{~h}$, followed by coverslip mounting with the ProLong ${ }^{\bullet}$ Gold anti-fade reagent with DAPI (Life Technologies). Samples were imaged on a Leica TCS SPE confocal microscope in the Confocal Imaging Core at The University of Kansas Medical Center. Images were collected and analyzed using the Leica LAS AF Lite software (Leica Biosystems, Nussloch, Germany). For quantification, mean fluorescent intensity was determined using Image J software on green (FITC) channel images.

\section{Electron microscopy}

$1 \times 10^{6}$ cells were seeded in 6-well plates and treated after an overnight acclimatization. After $72 \mathrm{~h}$ of treatment cells were harvested by scraping and fixed for $24 \mathrm{~h}$ at $4{ }^{\circ} \mathrm{C}$ in $0.1 \mathrm{M}$ cacodylate buffer supplemented with $2 \%$ glutaraldehyde. Samples were then processed in The Electron Microscopy Research Laboratory at KU Medical Center as follows. Briefly, cell pellets were washed in $0.1 \mathrm{M}$ cacodylate buffer for $10 \mathrm{~min}$, and resuspended. Cell pellets were post fixed in $1 \%$ osmium tetroxide buffered in $0.1 \mathrm{M}$ cacodylate, rinsed in distilled water 3X's and then dehydrated in a graded series of ethanol as follows: $50 \%, 70 \%, 80 \%, 95 \%, 100 \%, 100 \% 10 \mathrm{~min}$ each step. Cells were placed into propylene oxide for $20 \mathrm{~min}$, then into a 50:50 mixture of propylene oxide and Embed 812 resin medium overnight at room temperature. Samples were cured overnight in beem capsules at 60 degrees and then sectioned with a diamond knife on a Leica UC-7. Sections were cut at $80 \mathrm{~nm}$ and contrasted with uranyl acetate and lead citrate and imaged on a JEOL 100CX II Transmission Electron Microscope (Tokyo, Japan).

\section{Statistical analysis}

At least three separate experiments were performed for each measurement unless otherwise indicated. All quantitative data were expressed as means with error bars representing 1 standard deviation (mean $\pm 1 \mathrm{SD}$ ). Comparisons between two treatments were analyzed using a two-way student t-test with $P$-value of $<0.05$ considered to be statistically significant. $* p<0.05, * * p<0.01, * * * p<0.001$ unless otherwise indicated.

\section{Results}

Everolimus inhibits proliferation through induction of G1 arrest

We tested the anti-proliferative effect of everolimus in two AI-resistant breast cancer cell lines, MCF-7:5C and MCF-7:2A and their parental AI-sensitive cell line, MCF-7. We found that everolimus inhibited the proliferation of MCF-7:5C and MCF-7:2A cells with relatively equal efficiency compared to MCF-7 breast cancer cells (Fig. 1a, upper panel). The $\mathrm{IC}_{50}$ values for MCF-7, MCF7:5C and MCF-7:2A cells were $25 \mathrm{nM}, 38 \mathrm{nM}$ and 20 $\mathrm{nM}$, respectively, indicating only minor differences in sensitivity to everolimus between these cell lines (Fig. 1a, lower panel). Treatment with $20 \mathrm{nM}$ everolimus achieved maximal inhibition of all three cell lines (Fig. 1a) as early as $24 \mathrm{~h}$ post-treatment (Fig. 1b). Additionally, the everolimus mediated inhibition of proliferation could be maintained with treatment every three days under clonogenic assay conditions (Fig. 1c). In contrast, everolimus had no effect on the proliferation of the immortalized normal 

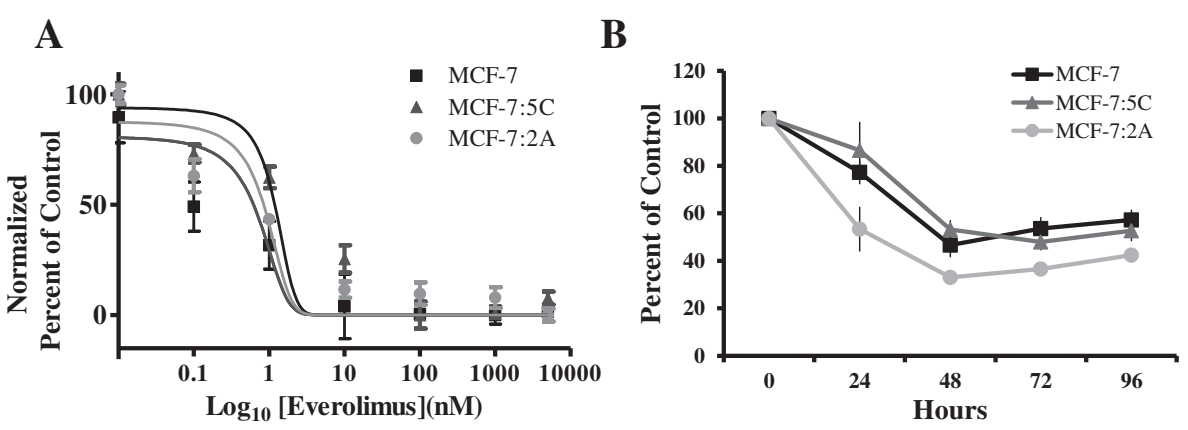

\begin{tabular}{|c|c|}
\hline Cell Line & IC $_{\mathbf{5 0}}$ \\
\hline MCF-7 & $25 \mathrm{nM} \pm 1.9$ \\
MCF-7:5C & $38 \mathrm{nM} \pm 2.3$ \\
MCF-7:2A & $20 \mathrm{nM} \pm 2.1$ \\
\hline
\end{tabular}
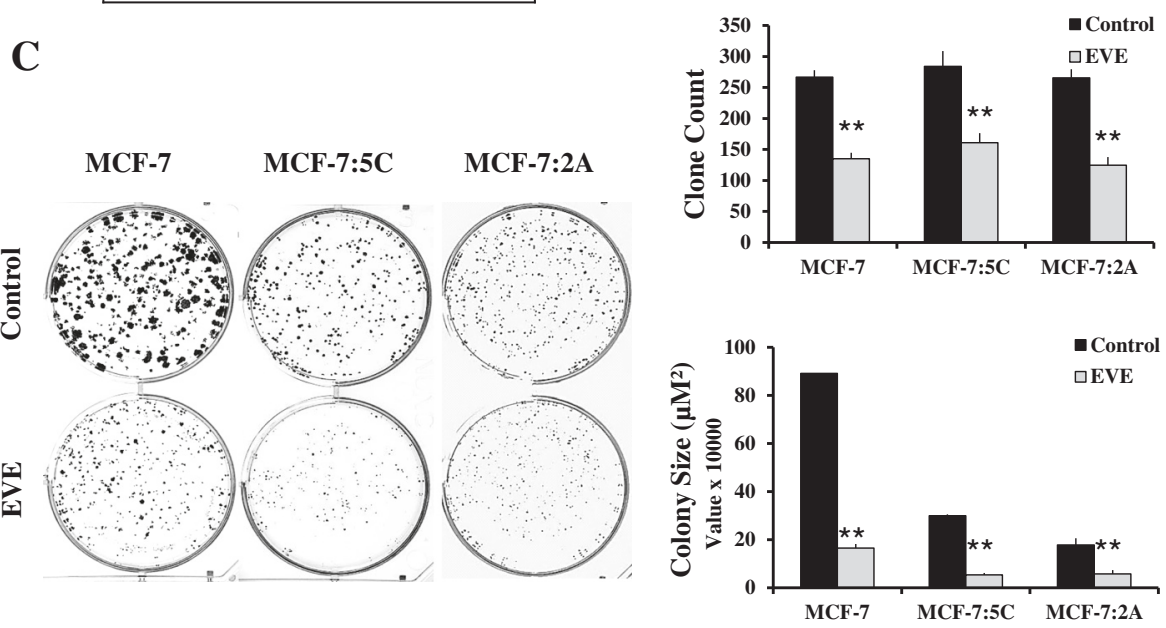

Fig. 1 Everolimus inhibits the proliferation of Al-sensitive and Al-resistant breast cancer cells. a MCF-7, MCF-7:5C and MCF-7:2A cells were treated with $20 \mathrm{nM}$ everolimus or vehicle (control) for $72 \mathrm{~h}$. The percent of viable cells after everolimus treatment was determined by cell viability assay and compared to control. $I_{50}$ values for each of the cell lines were determined by nonlinear regression on normalized values. Values represent means of three experiments conducted in quadruplet. b MCF-7, MCF-7:5C and MCF-7:2A cells were seeded in 24-well plates and treated with $20 \mathrm{nM}$ everolimus or vehicle after overnight acclimatization (Day 0). The percentage of viable cells was determined at 24, 48, 72 and $96 \mathrm{~h}$ post treatment by comparison to vehicle treated cells. c Cells were seeded in single cell suspension and allowed to proliferate for 9 days in the presence of 20nM everolimus or vehicle (control). The plates were photographed at 1X magnification (left panel) and the number of colonies and colony size were quantified using Image J (right panel). Bar graphs represent the data from three independent experiments in triplicate and values are mean $\pm S D .{ }^{* *} p<0.01$

breast epithelium cell line, MCF10A (Additional file 1: Figure S1a and b).

Cell cycle analysis of MCF-7, MCF-7:5C, and MCF$7: 2 \mathrm{~A}$ cells treated with everolimus indicated that the anti-proliferative effect of the drug was due to G1 arrest. The percentage of cells in G1 phase increased by at least $20 \%$ in all three cells lines as early as $24 \mathrm{~h}$ after treatment (Fig. 2a) and this persisted through $72 \mathrm{~h}$ (Fig. 2b). Everolimus had no effect on the cycling of the normal breast epithelial cell line MCF10A (Additional file 1: Figure S1c). Additionally, we found that the expression of cyclin D1 and p21 were significantly reduced in MCF7, MCF-7:5C and MCF-7:2A cells 48 and $72 \mathrm{~h}$ after treatment (Fig. 2c). This data indicates that everolimus is effective at inhibiting the proliferation of breast cancer cells due to marked induction of G1 arrest.

\section{Everolimus reduces the anchorage-independent growth}

The ability of cancer cells to grow in an anchorageindependent manner is a critical marker of tumor forming and metastatic potential. We compared the abilities of MCF-7, MCF-7:5C and MCF-7:2A cells to grow in an anchorage-independent manner using the soft-agar 3D colony formation assay. We found that MCF-7:5C cells produced three times more 3D colonies than the MCF-7 and MCF-7:2A cells. Additionally, $20 \mathrm{nM}$ everolimus significantly reduced the number of $3 \mathrm{D}$ colonies in all three cell lines (Fig. 3a). The 3D colonies formed by the MCF- 

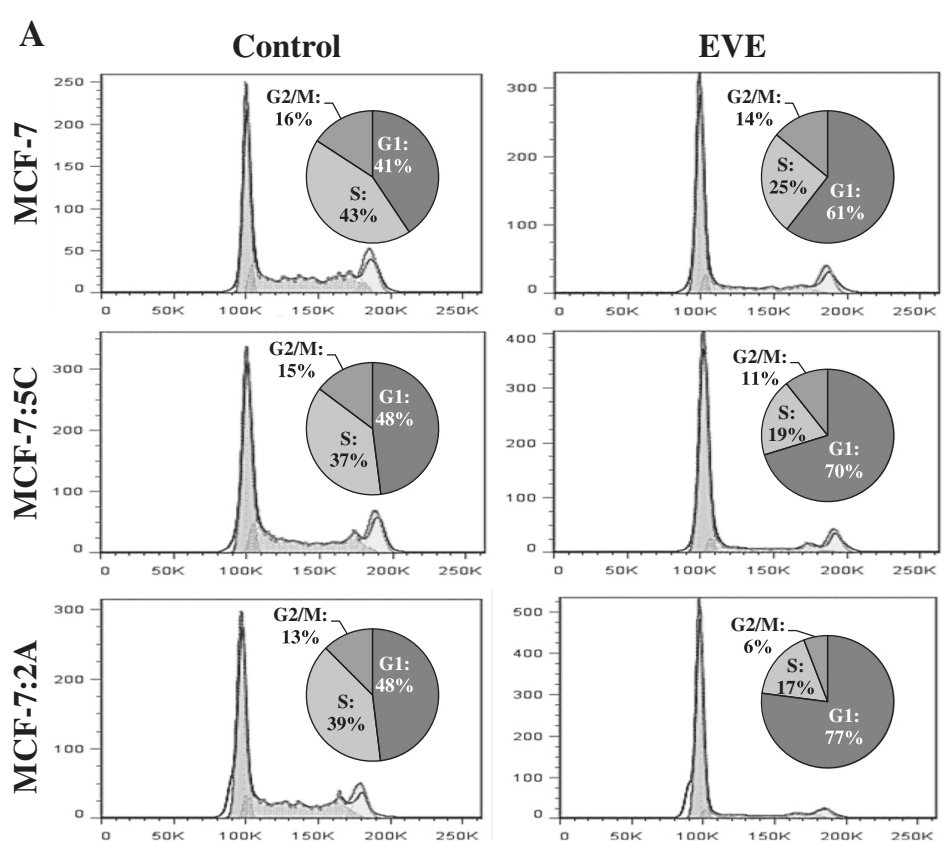

B

\begin{tabular}{|c|cc|cc|cc|}
\hline \multirow{2}{*}{ Cell Line } & \multicolumn{2}{|c|}{ 24 Hours } & \multicolumn{2}{c|}{ 48 Hours } & \multicolumn{2}{c|}{ 72 Hours } \\
& Control & EVE** & Control & EVE** & Control & EVE** \\
\hline MCF-7 & $42.5 \pm 4$ & $60.7 \pm 9$ & $50.2 \pm 5$ & $62.2 \pm 1$ & $58.9 \pm 1$ & $66.1 \pm 2$ \\
MCF-7:5C & $48.1 \pm 5$ & $73.1 \pm 6$ & $56.5 \pm 2$ & $69.9 \pm 4$ & $57.8 \pm 2$ & $69.1 \pm 4$ \\
MCF-7:2A & $55.2 \pm 7$ & $74.4 \pm 2$ & $51.1 \pm 2$ & $70.3 \pm 9$ & $55.9 \pm 4$ & $68.8 \pm 8$ \\
\hline
\end{tabular}

C

$48 \mathrm{Hrs}$

$72 \mathrm{Hrs}$
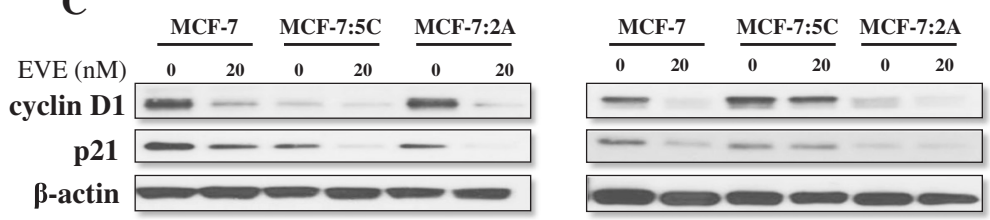

Fig. 2 Everolimus induces G1 arrest. a MCF-7, MCF-7:5C and MCF-7:2A cells were treated for $24 \mathrm{~h}$ with $20 \mathrm{nM}$ everolimus or vehicle and then harvested by trypsinization. Samples were fixed with methanol, stained with propidium iodide and analyzed by flow cytometry. The percent of cells in each phase of the cell cycle from a representative experiment are indicated in pie charts. $\mathbf{b}$ Samples from cells treated for 24,48 and $72 \mathrm{~h}$ are summarized in the table. Values are means from three independent experiments analyzed in duplicate and are displayed as mean \pm SD. ** $p<0.01$. c Cyclin D1 and p21 expression in MCF-7, MCF-7:5C and MCF-7:2A cells following treatment with everolimus (20 nM) for 48 and $72 \mathrm{~h}$

7:5C cells averaged $18 \mu \mathrm{M}^{2}$, while those formed by the MCF-7 and MCF-7:2A cells averages 40 and $35 \mu \mathrm{M}^{2}$ respectively. Upon microscopic inspection, we found that $20 \mathrm{nM}$ everolimus dramatically reduced the size of $3 \mathrm{D}$ colonies in all three cell lines, with the most pronounced effect being on the MCF-7:5C cells (Fig. 3b). These data indicate that everolimus inhibits not just the proliferation of breast cancer cells, but also their tumor forming and metastatic potential.

\section{Effects of everolimus on the PI3K/Akt/mTOR pathway}

We also examined the effect of everolimus treatment on the activation of the PI3K/Akt/mTOR pathway. We found that everolimus significantly inhibited mTOR phosphorylation as early as $30 \mathrm{~min}$ post treatment but not Akt, p70S6K and 4EBP1 (Fig. 4, upper panels). Everolimus inhibited the phosphorylation of downstream members of the PI3K/Akt/mTOR pathway at $12 \mathrm{~h}$. This was most prominent at $24 \mathrm{~h}$ in MCF-7, MCF-7:5C and MCF-7:2A cells (Fig. 4, bottom panels). $25 \mathrm{nM}$ everolimus was sufficient to inhibit PI3K/mTOR/Akt signaling at 12 and $24 \mathrm{~h}$ but higher doses were more effective at blocking phosphorylation. Notably, inhibition of p70S6K phosphorylation was observed by $60 \mathrm{~min}$ in the AIsensitive MCF-7 cell line, especially with higher doses, but not in the AI-resistant MCF-7:5C and MCF-7:2A cells until $12 \mathrm{~h}$ post-treatment (Fig. 4). Reduction of phospho- mTOR, p70S6K and Akt were maintained by $20 \mathrm{nM}$ everolimus through 48 and $72 \mathrm{~h}$ (Additional file 2: Figure S2). Everolimus successfully targets the Akt/ 

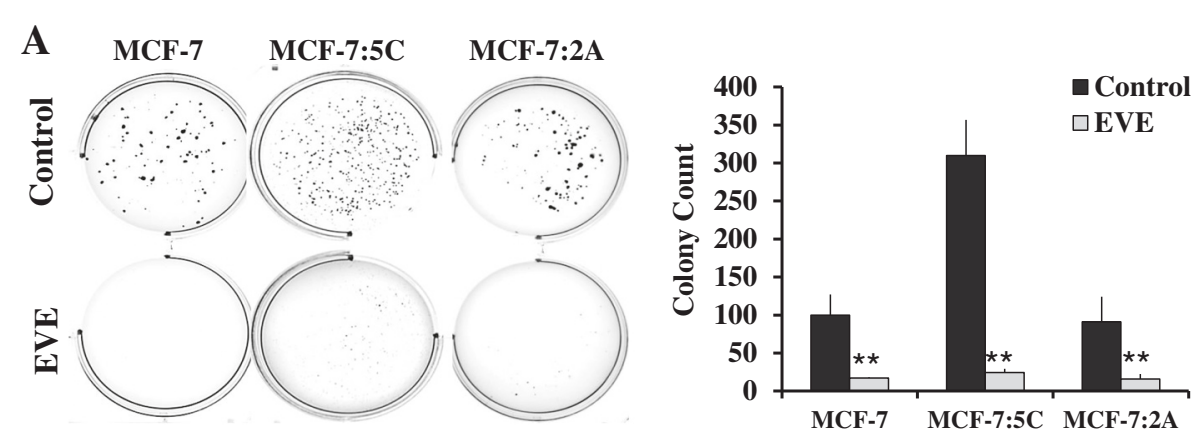

B
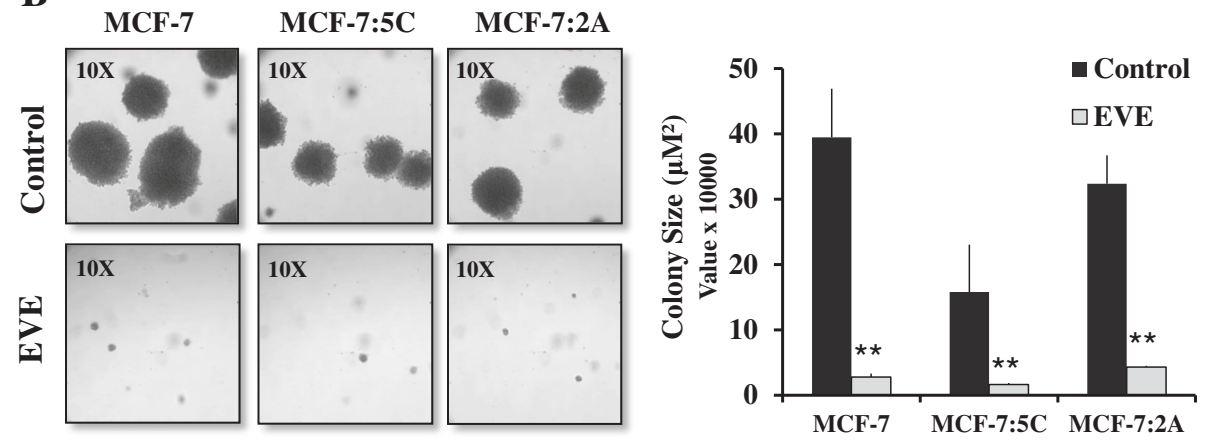

Fig. 3 Everolimus reduces anchorage-independent growth. a MCF-7, MCF-7:5C and MCF-7:2A cells were seeded in single cell suspension within a layer of $0.5 \%$ agarose gel. Cells were treated with $20 \mathrm{nM}$ everolimus or vehicle every $48 \mathrm{~h}$ for 17 days. Images were taken at $1 \mathrm{X}$ magnification and the number of colonies quantified using Image J. $\mathbf{b}$ Images of the same wells were taken at 10X magnification and colony diameter in $\mu m^{2}$ is shown. Bar graphs represent the data from three independent experiments in duplicate. The displayed values are mean \pm SD. ${ }^{* *} p<0.01$

mTOR pathway in AI-sensitive and AI-resistant breast cancer cells.

\section{Everolimus reduces estrogen receptor (ER) expression and transcriptional activity}

The activity of ER can be regulated by the PI3K/Akt/ mTOR pathway and is critical to the survival and proliferation of AI-sensitive MCF-7 cells, as well as the AIresistant MCF-7:5C and MCF-7:2A cell lines. The ligand-independent activity of ER maintains the growth and survival of AI-resistant breast cancer cells [35, 36]. We found that treatment with everolimus significantly reduced ER transcriptional activity and protein expression (Fig. 5a and b). This was compared to the action of the pure anti-estrogen fulvestrant (Fig. 5a and b). Everolimus also dramatically reduced $\mathrm{ER} \alpha$ mRNA expression (Fig. 5c) in addition to protein expression of the ER chaperone, HSP90 (Fig. 5d). Downregulation of ER expression was confirmed by immunofluorescent confocal microscopy (Fig. 5e). Notably, there was higher ER transcriptional activity in AI-resistant MCF-7:5C and MCF7:2A cells compared to parental MCF-7 cells, confirming estrogen-independent ER action in the resistant cells (Fig. 5a). Taken together, these data indicate that everolimus, and therefore PI3K/Akt/mTOR signaling, is capable of regulating ER expression and transcriptional activity in both wild-type MCF-7 cells and AI-resistant MCF-7:5C and MCF-7:2A cells.

\section{Everolimus reverses 4-OH tamoxifen resistance}

Due to earlier studies that have found synergy between tamoxifen and everolimus in endocrine-sensitive breast cancer cell models and patients, we investigated the efficacy of this combination in our MCF-7, MCF-7:5C and MCF-7:2A cells. We have previously shown that the AIresistant $\mathrm{MCF}-7: 5 \mathrm{C}$ cells are not responsive to $4 \mathrm{OHT}$, whereas MCF-7:2A are partially sensitive to 4OHT [36]. In this study, $1 \mu \mathrm{M} 4 \mathrm{OHT}$ significantly inhibited the proliferation of MCF-7 and MCF-7:2A cells, reducing the number of $2 \mathrm{D}$ colonies by $20 \%$ and $10 \%$ respectively, but had no effect on MCF-7:5C cells (Fig. 6a). Treatment with $20 \mathrm{nM}$ everolimus for 9 days significantly reduced the proliferation of all three cell lines, reducing colony numbers by $~ 60 \%$ (Fig. 6a). Co-treatment of MCF-7, MCF-7:5C and MCF-7:2A cells with $1 \mu \mathrm{M} 4 \mathrm{OHT}$ and $20 \mathrm{nM}$ everolimus reduced colony formation in MCF-7 and MCF-7:2A cells by $\sim 95 \%$ and also had added benefit in the $4 \mathrm{OHT}$ resistant MCF-7:5C cells, bringing the anti-proliferative effect from $60 \%$ to $76 \%$. Synergy between $4 \mathrm{OHT}$ and everolimus treatment was present despite reductions in ER $\alpha$ expression in all three cell lines (Fig. 6b). This data supports clinical observations that the combination of 


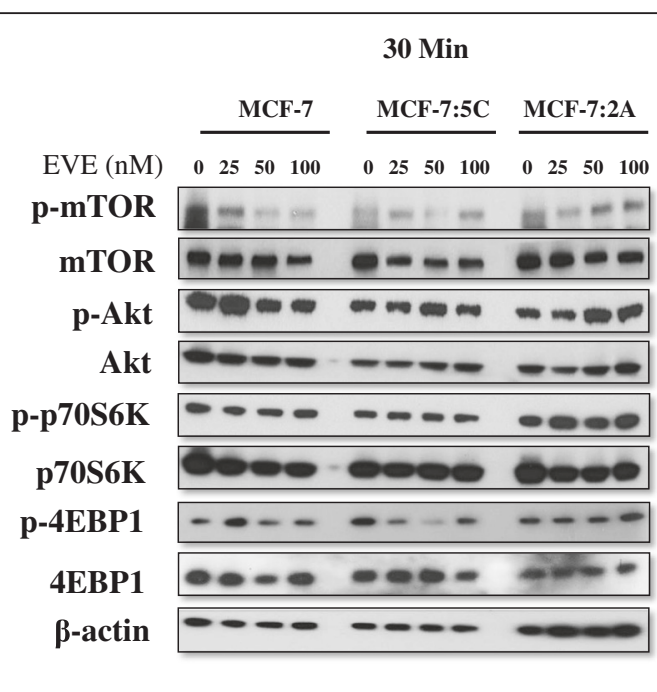

$12 \mathrm{Hrs}$

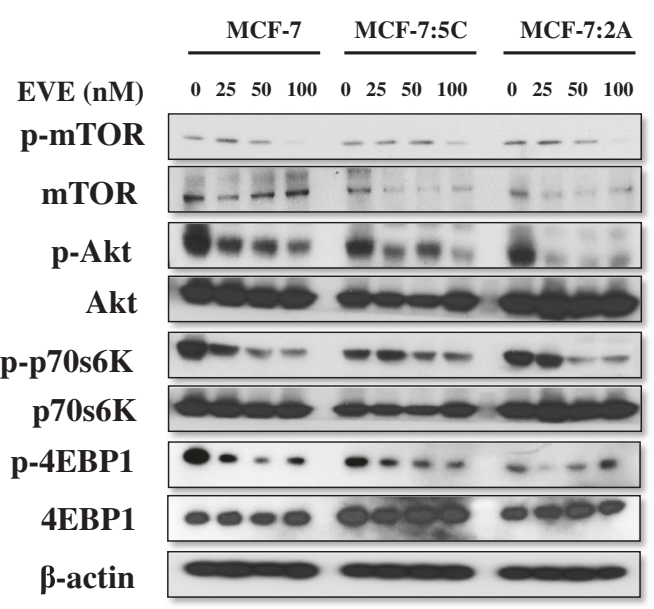

60 Min

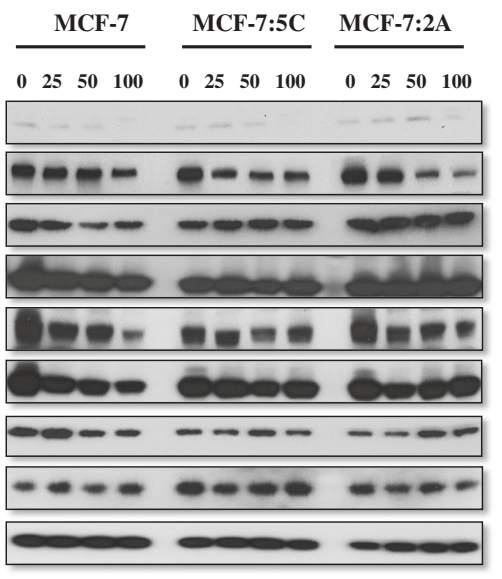

24 Hrs

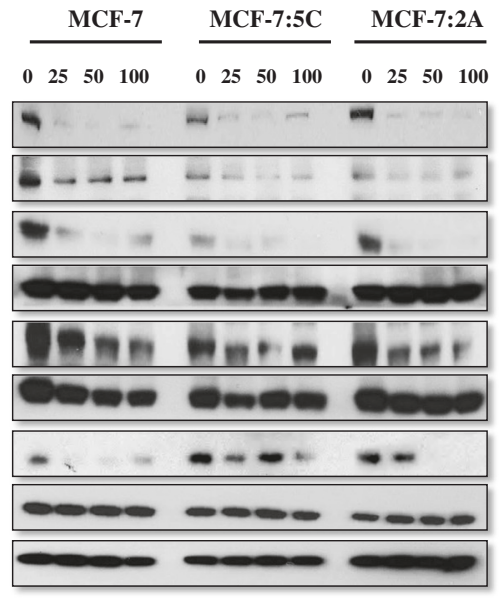

Fig. 4 Everolimus targets the mTOR/Akt pathway. Al-sensitive MCF-7 and Al-resistant MCF-7:5C and MCF-7:2A cells were treated with 25, 50 and 100nM everolimus. Phosphorylation of mTOR, AKT, p70s6K, 4EBP1 and total protein levels are shown at 30mins, 60mins, 12 and $24 \mathrm{~h}$. Images are representative of three independent experiments

tamoxifen with everolimus has therapeutic benefit in patients with ER+ breast cancer and can re-sensitize AIresistant breast cancer to endocrine therapy.

\section{Everolimus induces autophagy in breast cancer cells, which mediates insensitivity}

We investigated whether everolimus treatment induced autophagy in MCF-7, MCF-7:5C and MCF-7:2A cells. We found that everolimus reduced the levels of HSP70 and HSP27 in all three cell lines (Fig. 7a). Interestingly, everolimus also induced PARP cleavage (Fig. 7a); however, this was not associated with apoptosis by annexin v/PI staining (data not shown). Chloroquine was used as an autophagic flux inhibitor, and basal autophagy was assessed with and without everolimus treatment. Both immunofluorescent microscopy and western blot (Fig. 7b and $7 \mathrm{c}$ ), indicate that everolimus markedly enhanced
LC3-II above basal level, respectively. A lysosomal protease inhibitor cocktail $(100 \mu \mathrm{M}$ leupeptin, $10 \mu \mathrm{g} / \mathrm{mL}$ pepstatin A and $10 \mu \mathrm{g} / \mathrm{mL}$ e-64d for $24 \mathrm{~h}$ ) was also used to inhibit autophagic flux but results were not as robust as with $50 \mu \mathrm{M}$ chloroquine (data not shown). As further indication of everolimus' ability to induce autophagy, the number of autophagosomes identified by electron microscopy in all three cell lines was also increased (Fig. 8a and $8 \mathrm{~b})$. Combined inhibition of autophagy with $50 \mu \mathrm{M}$ CQ significantly improved the efficacy of everolimus treatment on cell proliferation, indicating that autophagy is a method of everolimus insensitivity in MCF-7 cell lines (Fig. 8c). Under normal conditions, the MCF-7:5C cell line displayed dilated endoplasmic reticulum, and both AI-resistant cell lines had pleomorphic mitochondria, indicating that aberrant metabolism is likely part of the phenotype of these AI-resistant breast cancer models 

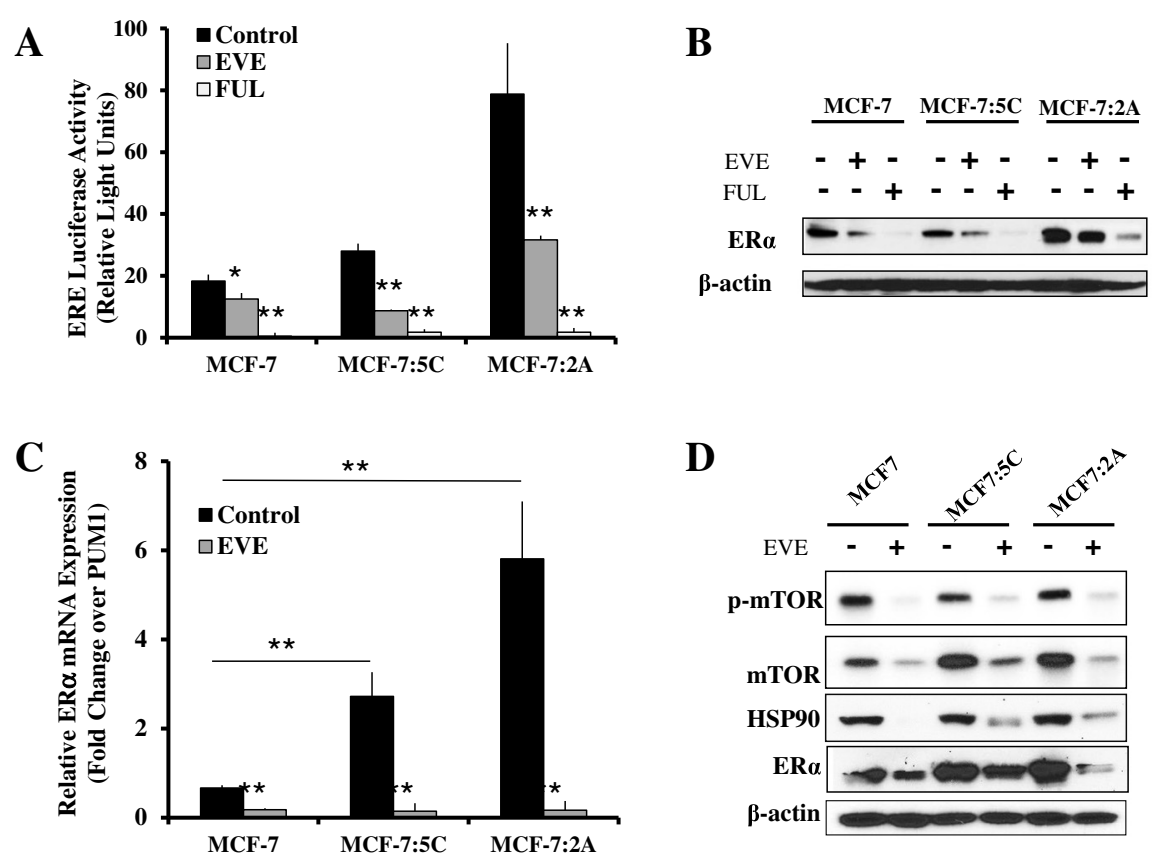

D
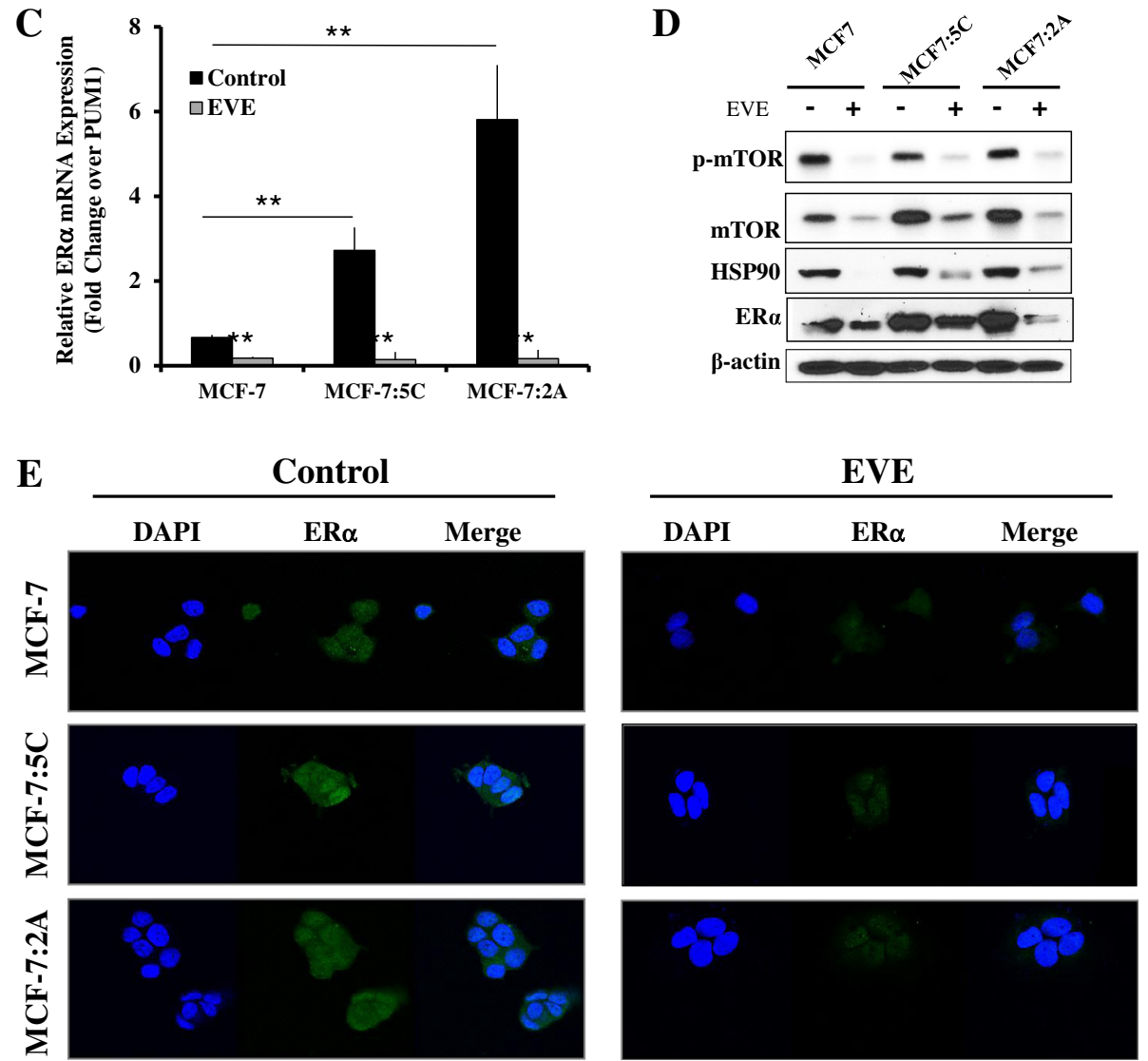

Fig. 5 Everolimus treatment inhibits estrogen receptor a expression and activity. a ER transcriptional activity after $24 \mathrm{~h}$ treatment of MCF-7, MCF-7:5C and MCF-7:2A cells with $20 \mathrm{nM}$ everolimus (EVE) and $1 \mu \mathrm{M}$ fulvestrant (FUL) is demonstrated using an ERE luciferase reporter. b Corresponding expression of estrogen receptor a (ERa) after $48 \mathrm{~h}$ of treatment is shown by western blot. $\mathbf{c}$ RT-PCR demonstrates the impact of $20 \mathrm{nM}$ everolimus on ERa mRNA production in all three cell lines after $24 \mathrm{~h}$. $\mathbf{d}$ The effect of everolimus treatment on mTOR phosphorylation as well as HSP90 and ERa expression is shown. e Immunofluorescent confocal microscopy illustrates the impact of $20 \mathrm{nM}$ everolimus on ERa expression and localization (green). Cell nuclei are stained with DAPI (blue). Bar graphs represent means from two independent experiments analyzed in quadruplet and are displayed as mean \pm SD. ${ }^{* *} p<0.01$

(Fig. 8a). These data suggest that MCF-7, MCF-7:5C and MCF-7:2A cells use autophagy as a method of everolimus resistance and that this response may be inhibited to improve the efficacy of everolimus treatment in breast cancer.

\section{Discussion}

This study was conducted to provide mechanistic insights into the anti-proliferative effects of everolimus in
AI-resistant MCF-7:5C and MCF-7:2A breast cancer cells, and AI-sensitive MCF-7 cells. We found that everolimus was equally effective against all three breast cancer cell lines. The anti-proliferative mechanisms included downregulation of ER expression and transcriptional activity, possibly through the suppression of HSP90. We also demonstrated that everolimus enhanced 4OHT sensitivity in all three cell lines. Everolimus treatment significantly induced autophagy, which was associated with downregulation of 

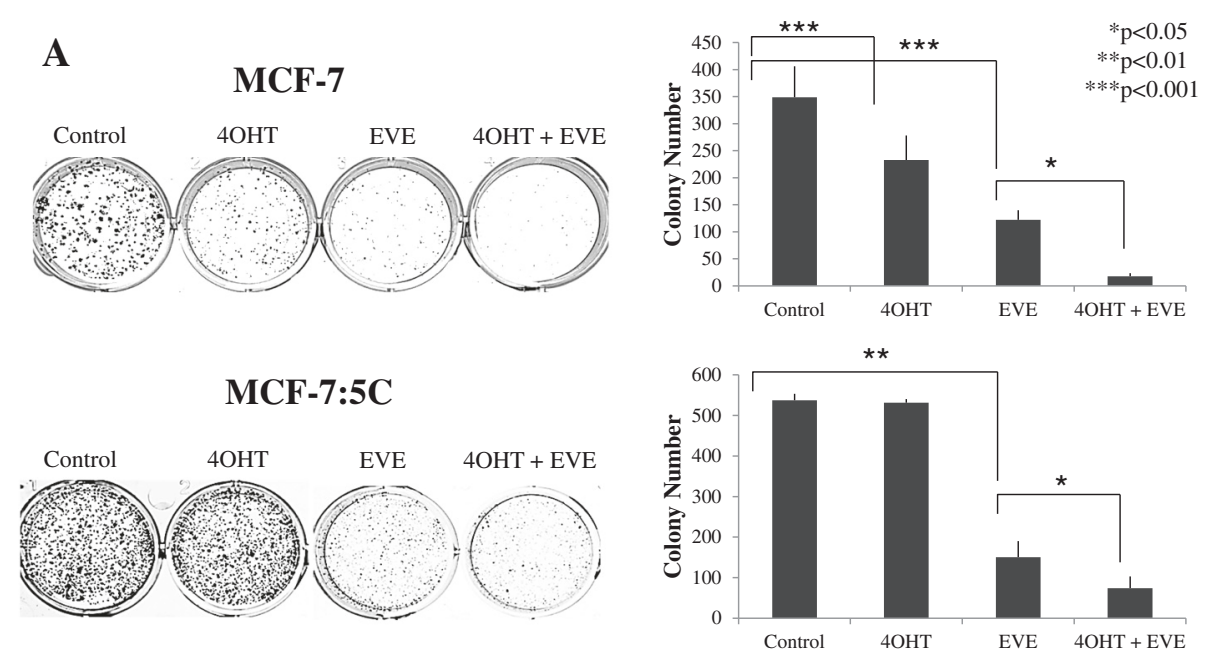

\section{MCF-7:2A}
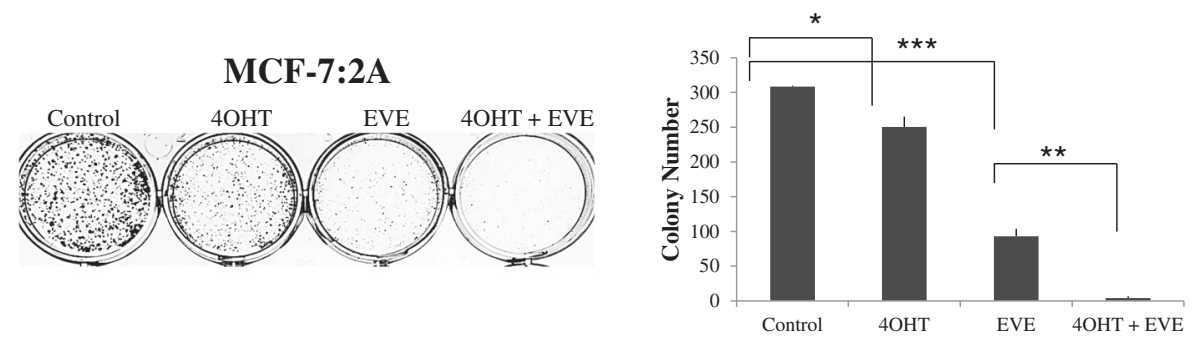

B

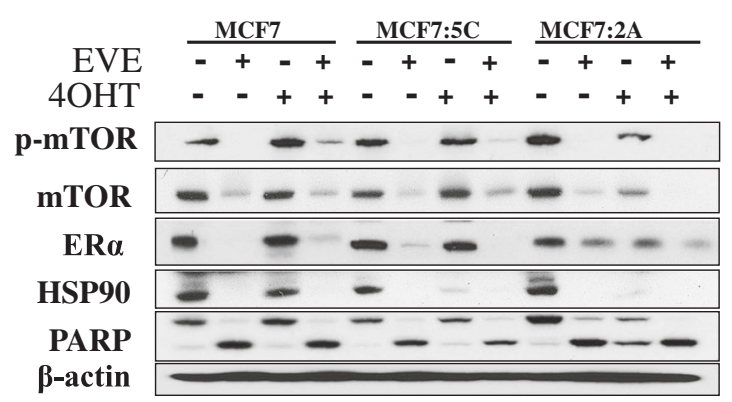

Fig. 6 Everolimus enhances tamoxifen sensitivity. a MCF-7, MCF-7:5C and MCF-7:2A cells were seeded in single cell suspension and allowed to proliferate for 9 days in the presence of $20 \mathrm{nM}$ everolimus, $1 \mu \mathrm{M}$ 4-hydroxy tamoxifen (4OHT) or vehicle for $48 \mathrm{~h}$. The plates were photographed and the number of colonies was quantified using Image J. Bar graphs represent the data from three independent experiments in triplicate and values are mean $\pm \mathrm{SD} .{ }^{*} p<0.05,{ }^{* *} p<0.01 .{ }^{* *} p<0.001$. $\mathbf{b}$ Western blot indicates the effect of each treatment on mTOR phosphorylation and ERa, HSP90 expression and cleaved PARP

HSP70 and HSP27 expression. Additionally, we confirmed that everolimus inhibits the activation of the PI3K/Akt/ mTOR pathway, resulting in the downregulation of cyclin D1 and p21 expression, which induced G1 arrest.

MCF-7 cells and their derivatives are more resistant to everolimus as compared to other luminal A breast cancer cell lines [37, 38]. Our study is consistent with this observation, as total inhibition of the MCF-7, MCF-7:5C and MCF-7:2A cells did not exceed $60 \%$, making them suitable to model a patient population that is not highly sensitive to everolimus. Additionally, our $\mathrm{IC}_{50}$ values were consistent with the frequent use of $20 \mathrm{nM}$ everolimus when studying MCF-7 cell lines $[17,39,40]$. The enhanced insensitivity of the MCF-7:5C cells may be due to increased expression of c-myc, which is thought to confer some resistance in ER+ breast cancer [41, 42]. The slightly enhanced sensitivity of the MCF-7:2A cells to everolimus may be related to comparatively lower levels of PTEN [42]. It should be noted that the MCF-7 and MCF-7:2A cells are progesterone receptor-positive (PR+), while the MCF-7:5C cells are PR-negative (PR-) and they overexpresses interferon stimulated genes [43]. These differences do not seem to mediate any variances in everolimus sensitivity, suggesting that the MCF-7 background of these cell lines is the most prominent determinant of response.

Elevated ER expression and signaling has been observed in both endocrine resistance cells and endocrine 

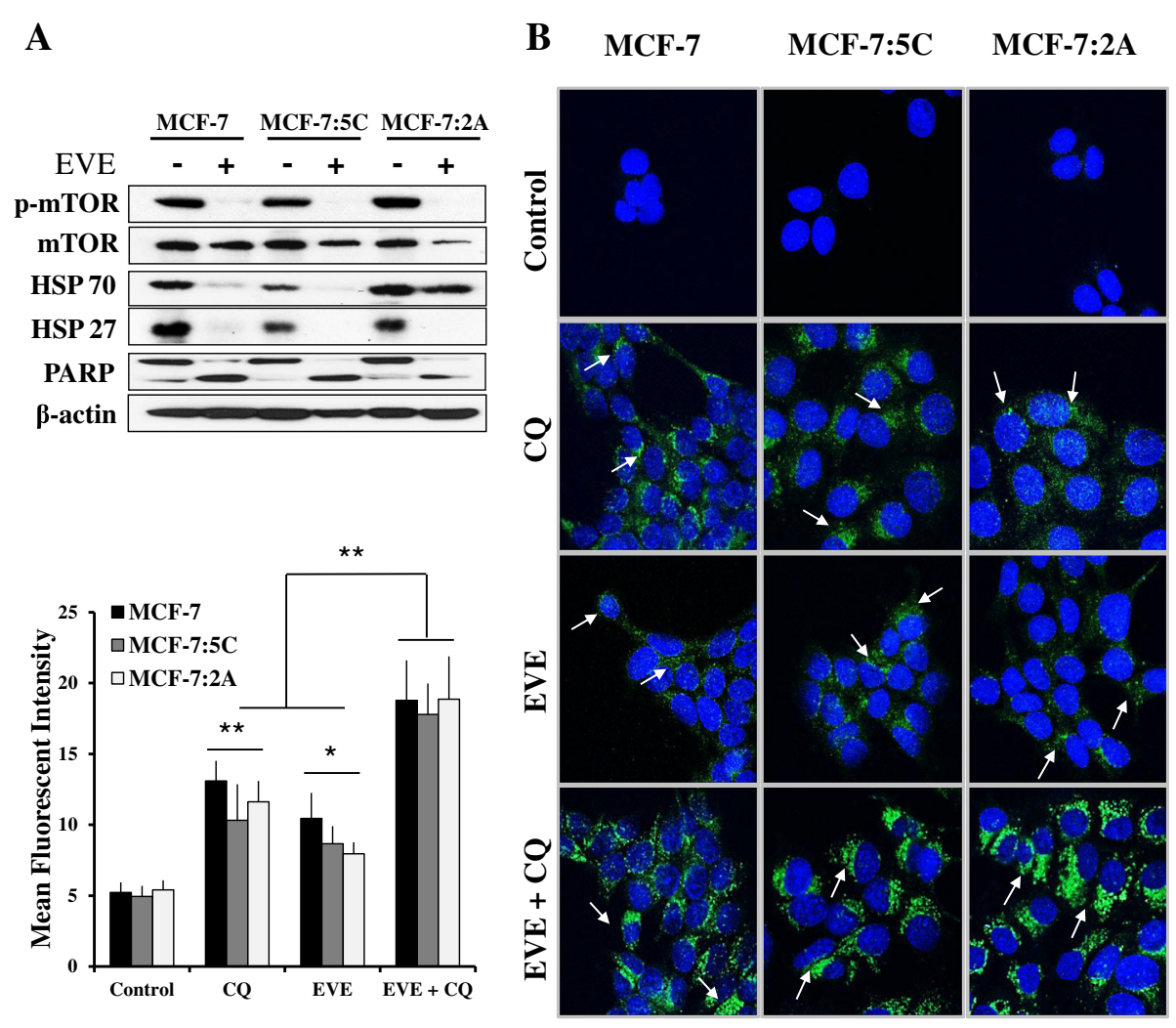

C
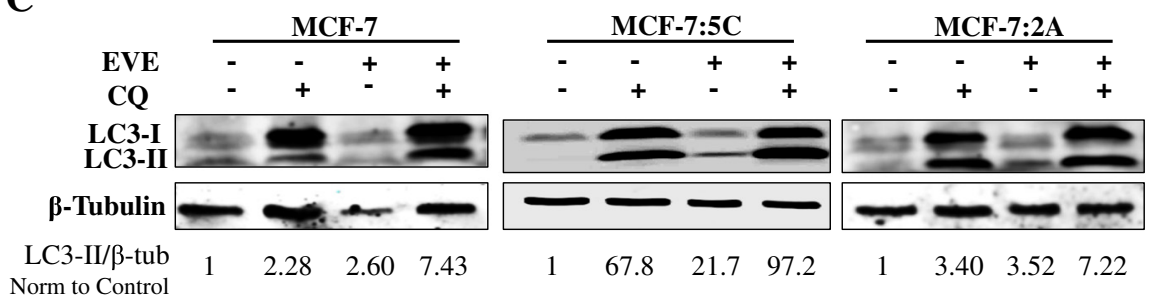

Fig. 7 Everolimus modifies autophagic cell markers. a Inhibition of mTOR phosphorylation, downregulation of HSP70 and HSP27 as well as induction of PARP cleavage by $20 \mathrm{nM}$ everolimus are shown by western blot. b MCF-7, MCF-7:5C and MCF-7:2A cells were treated with vehicle, $20 \mathrm{nM}$ everolimus, $50 \mu \mathrm{M}$ chloroquine (CQ) or both for $24 \mathrm{~h}$. LC3B is shown by immunofluorescent confocal microscopy. Punctate LC3B granules (green) are indicated with white arrows. Cell nuclei are stained with DAPI (blue). Mean fluorescent intensity was determined using Image J. c Cells were treated with vehicle, $20 \mathrm{nM}$ everolimus, $50 \mu \mathrm{M}$ chloroquine (CQ) or both for $48 \mathrm{~h}$ and LC3-I and $-I I$ assessed by western blot. The ratio of LC3-II/ $\beta$-Tubulin normalized to control was determined by densitometry with Image $\mathrm{J}$ and is shown below the blots

resistant tumors [2, 3, 44, 45]. The ability of everolimus to reduce ER transcriptional activity and phospho-ER (p-ER) expression in MCF-7/LTED cells has been previously reported but was not assessed in wild type MCF-7 cells [15]. In our study, we found that the inhibition of ER transcriptional activity was due to profound downregulation of total ER expression in all cell models. MCF-7:5C and MCF-7:2A cells are selected clones maintained in estrogen-free media that have retained ER transcriptional activity by upregulation of ER expression and ligand-independent ER signaling. In contrast, the MCF-7/LTED cells are a mixed population of cells that have developed hypersensitivity to estrogen [46]. Additionally, the studies by Martin and colleagues were conducted after acute insulin deprivation, which probably contributed to the enhanced sensitivity to everolimus and to the impact on both p-ER and p-Akt expression in their study. The clinical efficacy of everolimus as a solo agent was thought to be limited by a compensatory increase in Akt phosphorylation through mTORC2 [17]. We did not observe this reflexive increase in Akt phosphorylation in our cells lines. Our results suggest that 


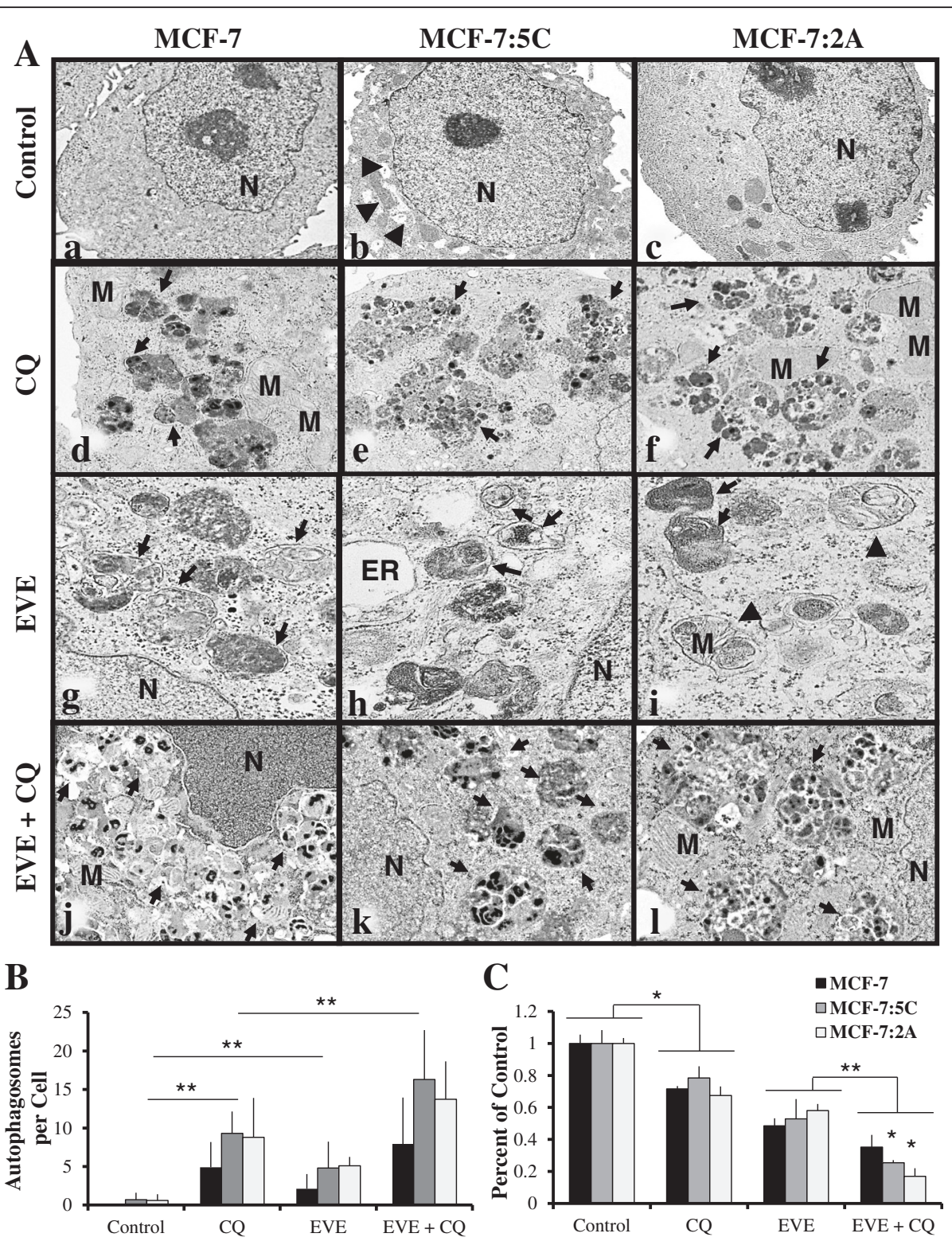

Fig. 8 Everolimus treatment induces autophagy, which mediates insensitivity. a MCF-7, MCF-7:5C and MCF-7:2A cells were treated with vehicle $(\mathrm{a}-\mathrm{c}), 50 \mu \mathrm{M}$ chloroquine (CQ) (d-f), $20 \mathrm{nM}$ everolimus (EVE) ( $\mathrm{g}-\mathrm{i})$ or both EVE and CQ ( $\mathrm{j}-\mathrm{l})$ for $48 \mathrm{~h}$ and imaged using electron microscopy. Arrows indicate double membrane bound autophagosomes and arrow heads indicate pleomorphic mitochondria and dilated endoplasmic reticulum, which could also be seen in untreated MCF-7:5C cells. Images a-c are shown at $2000 \mathrm{X}$ magnification while $d-f, g-i$ and $j-l$ are shown at 5000X $8000 \mathrm{X}$ and 6000X respectively. M, mitochondria; N, nucleus; ER, endoplasmic reticulum. b Autophagosomes in a minimum of 10 random cells were recorded using de-identified samples. Values are average autophagosomes per cell and represent three trials from two separate experiments. $\mathbf{c}$ Cells were seeded in 24-well plates and treated with vehicle, $20 \mathrm{nM}$ everolimus (EVE), $50 \mu \mathrm{M}$ chloroquine or both for 7 days. The percentage of viable cells is shown as compared to vehicle treated cells. Bar graphs represent the data from three independent experiments in duplicate and values are mean \pm SD. ${ }^{*} p<0.05,{ }^{* *} p<0.01$

everolimus as a single agent has the ability to function in a manner similar to combination therapy by inhibiting both growth factor and ER signaling simultaneously in some systems. Downregulation of total ER expression by everolimus has not, to our knowledge, been previously reported.
The downregulation of ER expression was likely due to reduced expression of HSP90, a well-known ER chaperone. HSP expression in general is controlled by the PI3K/Akt/mTOR pathway through phosphorylation of the transcription factor HSF1 and is consistent with the loss of HSP90, HSP27 and HSP70 expression 
observed in this study [47]. Everolimus induced loss of HSP90 mRNA expression has been observed in other cancers [19] and a loss of HSP90 expression has been linked to autophagic cell death [48]. Two HSP90 inhibitors, NVP-AUY922 and STA-9090, are currently in clinical trials for the treatment of breast cancer $[49,50]$. HSP90 inhibitor therapy has been limited by reflexive increase in HSP signaling, especially enhanced HSP27 expression [51, 52]. Here, we report that everolimus inhibits HSP27 in our cell lines, and so may potentiate HSP90 inhibitor treatment. These results suggest that everolimus may be combined with HSP90 inhibitors or drugs that target HSP90 clients for the treatment of AIresistant breast cancer.

AI-resistant tumors are known to retain dependence on ER signaling for growth and survival. Given that everolimus reduces ER expression, our observation that it also enhances $4 \mathrm{OHT}$ sensitivity during long-term cotreatment is very interesting and warrants further investigation. It should be noted, however, that everolimus has previously been shown to inhibit ER phosphorylation on serine 167 despite documented synergy between everolimus and tamoxifen in AI-resistant models and patients $[10,15,17]$. It is likely that these two drugs exhibit synergy by targeting ER signaling through separate but complementary mechanisms. Our results indicate that everolimus reduces ER expression through inhibition of ER mRNA transcription, while tamoxifen targets the ER protein. Combining everolimus and tamoxifen ensures that ER signaling is inhibited continuously over time in all cells within a heterogeneous breast tumor. The improved efficacy of everolimus in combination with $4 \mathrm{OHT}$ in our study is consistent with results from the TAMRAD clinical trial, [10]. The data from our study suggest that everolimus could benefit AI-resistant patients with ligand-independent ER activity by targeting ER expression and signaling.

We have demonstrated that everolimus dramatically induces autophagy, and is associated with significant downregulation of HSP90, HSP70 and HSP27. Loss of HSP70 and HSP27 is associated with starvation-induced autophagy and rapamycin treatment, both of which target the PI3K/Akt/mTOR pathway [26, 30]. Autophagy is a mechanism of drug insensitivity in cancer because it allows tumors to recycle cellular components and survive treatment [21, 22]. Inhibition of autophagy significantly improved the anti-proliferative effects of everolimus in MCF-7, MCF-7:5C and MCF-7:2A cells. This is consistent with a previous study reporting enhanced inhibition of MCF-7 cell proliferation when combining chloroquine and everolimus [53]. Everolimus and other PI3K/Akt/ mTOR inhibitors are known to induce autophagy in both solid and blood tumors [19, 20]; however, to our knowledge, this phenomenon has not been reported in breast cancer cells. We conclude that the induction of autophagy is likely a mechanism of everolimus insensitivity in MCF-7 [37, 38], MCF-7:5C and MCF-7:2A cells.

Although everolimus treatment induced PARP cleavage in all three cell lines, we did not observe apoptotic cell death normally associated with PARP cleavage. PARP cleavage is thought to mediate autophagy rather than apoptosis in response to certain stimuli [54]. Since HSP70 is known to stabilize PARP [55], loss of HSP70mediated stability offers an explanation for the everolimus induced PARP cleavage seen in this study. While there have been reports of autophagic and apoptotic cell death in leukemia [19] and nasopharyngeal carcinoma cells [56], everolimus is not known to induce cell death in breast cancer cells on its own $[19,56]$. To our knowledge, everolimus induced cell death in breast cancer has only been observed in aromatase expressing MCF-7/Aro cells when combined with letrozole [7]. We have shown that induction of autophagy limits the anti-proliferative response of everolimus treatment, hence a combination of everolimus with the autophagy inhibitors chloroquine or hydroxychloroquine, which are currently in clinical trials as part of combination therapy [57], may be beneficial in the treatment of AI-resistant breast cancer.

\section{Conclusions}

Overall, this study demonstrated that everolimus inhibits the proliferation of AI-resistant breast cancer cells through down regulation of ER expression and also that induction of autophagy is a method of everolimus insensitivity. We found that everolimus had similar effect on the proliferation of both our AI-sensitive (MCF-7) and AI-resistant (MCF-7:5C and MCF-7:2A) models, suggesting that the MCF-7 background of these cell lines overrides any other differences that might impact everolimus sensitivity. The inhibition of proliferation was seen regardless of PR status, PTEN expression, type 1interferon signaling, and $4 \mathrm{OHT}$ sensitivity, supporting a conclusion that everolimus holds promise as part of combination therapy for a wide variety of AI-resistant patients, for whom AI treatment is not an option.

\section{Additional files}

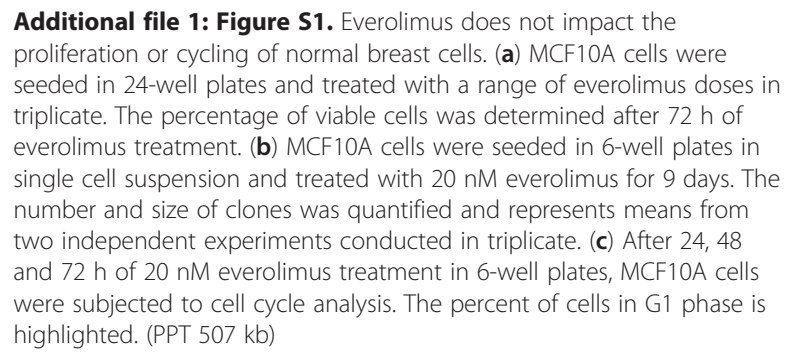


Additional file 2: Figure S2. Everolimus targets the phosphorylation of the PI3K/mTOR/Akt pathway at 48 and 72 h. MCF-7, MCF-7:5C and MCF-7:2A cells were seeded in 6-well plates and treated with 25,50 or $100 \mathrm{nM}$ everolimus or vehicle. Cells were harvested at 48 and $72 \mathrm{~h}$ and protein expression analyzed by western blot. Image represents three independent experiments. (PPT $674 \mathrm{~kb}$ )

\section{Abbreviations}

$\mathrm{Al}$, aromatase inhibitor; $\mathrm{CQ}$, chloroquine; $\mathrm{EGF}$, epidermal growth factor; $\mathrm{ER}$, estrogen receptor; EVE, everolimus; FUL, fulvestrant; HER2, human epidermal growth factor receptor 2; HIF-1a, hypoxia inducible factor 1 alpha subunit; HSP27, Heat shock protein 27; HSP70, heat shock protein 70; HSP90, heat shock protein $90 ; I_{50}$, drug concentration that provides $50 \%$ maximal growth inhibition; LC3B, Microtubule associated light chain 3; mTOR, mammalian target of rapamycin; PARP, Poly ADP ribose polymerase; PI3K, phosphoinositide 3-kinase; PR, Progesterone receptor; PTEN, phosphatase and tensin homolog; P21, cyclin dependent kinas inhibitor 1; p70S6K, p70 S6 ribosomal protein kinase; TSC, tuberous sclerosis complex; 4OHT, 4hydroxytamoxifenv; 4EBP1, Eukaryotic translation initiation factor 4E-bidning proteinv.

\section{Acknowledgements}

We would like to thank the Flow Cytometry Core Laboratory at the University of Kansas Medical Center, which is sponsored, in part, by the NIH/NIGMS COBRE grant P30 GM103326. We also wish to acknowledge the University of Kansas Medical Center Electron Microscopy Research Lab (EMRL) facility for assistance with the electron microscopy. The EMRL is supported in part, by NIH COBRE grant 9P20GM104936. The JEOL JEM-1400 TEM used in the study was purchased with funds from NIH grant S10RR027564.

\section{Funding}

This study was supported, in part, by grants from the Department of Defense (W81XWH-12-1-0139 to JLW), the National Cancer Institute (K01CA120051 to $J L W)$, start-up funds from the University of Kansas Medical Center (to JLW), the KUMC Biomedical Research Training Program (BRTP to AL), the National Cancer Institute (1F30CA203160-01 to AL), and the University of Kansas Cancer Center (CCSG grants P30 CA168524-0 to ST and JLW).

\section{Availability of data and materials}

All data supporting the findings in this study are included within the manuscript and the two supplementary figures.

\section{Authors' contributions}

AL designed and executed this study and wrote the manuscript. JN assisted with the experiments concerning analysis of autophagy and contributed to the manuscript. JO edited the manuscript and contributed intellectually to the study. ST oversaw the autophagy analysis and edited the manuscript. JLW, conceived of the study and edited the manuscript. All authors have read and approved the final manuscript.

\section{Competing interests}

The authors declare that they have no competing interests.

\section{Consent for publication}

Not Applicable.

\section{Ethics approval and consent to participate}

Not Applicable.

\footnotetext{
Author details

${ }^{1}$ Department of Molecular and Integrative Physiology, University of Kansas Medical Center, Kansas City, KS 66160, USA. ²Department of Anatomy and Cell Biology, University of Kansas Medical Center, Kansas City, KS 66160, USA. ${ }^{3}$ Department of Cancer Biology, University of Kansas Medical Center, Kansas City, KS 66160, USA. Department of Otolaryngology, University of Kansas Medical Center, Kansas City, KS 66160, USA. ${ }^{5}$ The University of Kansas Cancer Center, Kansas City, KS 66160, USA.
}

Received: 24 February 2016 Accepted: 30 June 2016 Published online: 16 July 2016

\section{References}

1. Cuzick J, Sestak I, Baum M, Buzdar A, Howell A, Dowsett M, Forbes JF. Effect of anastrozole and tamoxifen as adjuvant treatment for early-stage breast cancer: 10-year analysis of the ATAC trial. Lancet Oncol. 2010;11(12):1135-41.

2. Ali S, Coombes RC. Endocrine-responsive breast cancer and strategies for combating resistance. Nat Rev Cancer. 2002;2(2):101-12.

3. Clarke R, Liu MC, Bouker KB, Gu Z, Lee RY, Zhu Y, Skaar TC, Gomez B, O'Brien $K$, Wang $Y$, et al. Antiestrogen resistance in breast cancer and the role of estrogen receptor signaling. Oncogene. 2003;22(47):7316-39.

4. deGraffenried LA, Friedrichs WE, Russell DH, Donzis EJ, Middleton AK, Silva JM, Roth RA, Hidalgo M. Inhibition of mTOR activity restores tamoxifen response in breast cancer cells with aberrant Akt Activity. Clin Cancer Res. 2004;10(23):8059-67.

5. Kurokawa H, Arteaga CL. ErbB (HER) receptors can abrogate antiestrogen action in human breast cancer by multiple signaling mechanisms. Clin Cancer Res. 2003;9(1 Pt 2):511s-5s.

6. Barone I, Cui Y, Herynk MH, Corona-Rodriguez A, Giordano C, Selever J, Beyer A, Ando S, Fuqua SA. Expression of the K303R estrogen receptor-alpha breast cancer mutation induces resistance to an aromatase inhibitor via addiction to the PI3K Akt kinase pathway. Cancer Res. 2009;69(11):4724-32.

7. Boulay A, Rudloff J, Ye J, Zumstein-Mecker S, O'Reilly T, Evans DB, Chen S, Lane HA. Dual inhibition of mTOR and estrogen receptor signaling in vitro induces cell death in models of breast cancer. Clin Cancer Res. 2005;11(14):5319-28.

8. Ellard SL, Clemons M, Gelmon KA, Norris B, Kennecke H, Chia S, Pritchard K, Eisen A, Vandenberg T, Taylor M, et al. Randomized phase II study comparing two schedules of everolimus in patients with recurrent/ metastatic breast cancer: NCIC Clinical Trials Group IND.163. J Clin Oncol. 2009;27(27):4536-41.

9. Baselga J, Semiglazov V, van Dam P, Manikhas A, Bellet M, Mayordomo J, Campone M, Kubista E, Greil R, Bianchi G, et al. Phase II randomized study of neoadjuvant everolimus plus letrozole compared with placebo plus letrozole in patients with estrogen receptor-positive breast cancer. J Clin Oncol. 2009;27(16):2630-7.

10. Bachelot T, Bourgier C, Cropet C, Ray-Coquard I, Ferrero JM, Freyer G, Abadie-Lacourtoisie S, Eymard JC, Debled M, Spaeth D, et al. Randomized phase II trial of everolimus in combination with tamoxifen in patients with hormone receptor-positive, human epidermal growth factor receptor 2negative metastatic breast cancer with prior exposure to aromatase inhibitors: a GINECO study. J Clin Oncol. 2012;30(22):2718-24.

11. Beaver JA, Park BH. The BOLERO-2 trial: the addition of everolimus to exemestane in the treatment of postmenopausal hormone receptorpositive advanced breast cancer. Future Oncol. 2012;8(6):651-7.

12. Beck JT, Hortobagyi GN, Campone M, Lebrun F, Deleu I, Rugo HS, Pistilli B, Masuda N, Hart L, Melichar B, et al. Everolimus plus exemestane as first-line therapy in HR(+), HER2(-) advanced breast cancer in BOLERO-2. Breast Cancer Res Treat. 2014;143(3):459-67.

13. Noguchi S, Masuda N, Iwata H, Mukai H, Horiguchi J, Puttawibul P, Srimuninnimit V, Tokuda Y, Kuroi K, Iwase H, et al. Efficacy of everolimus with exemestane versus exemestane alone in Asian patients with HER2negative, hormone-receptor-positive breast cancer in BOLERO-2. Breast Cancer. 2014;21(6):703-14.

14. Yardley DA, Noguchi S, Pritchard Kl, Burris 3rd HA, Baselga J, Gnant M, Hortobagyi GN, Campone M, Pistilli B, Piccart M, et al. Everolimus plus exemestane in postmenopausal patients with $\mathrm{HR}(+)$ breast cancer: BOLERO2 final progression-free survival analysis. Adv Ther. 2013;30(10):870-84.

15. Martin LA, Pancholi S, Farmer I, Guest S, Ribas R, Weigel MT, Thornhill AM, Ghazoui Z, A'Hern R, Evans DB, et al. Effectiveness and molecular interactions of the clinically active $\mathrm{MTORC} 1$ inhibitor everolimus in combination with tamoxifen or letrozole in vitro and in vivo. Breast Cancer Res. 2012;14(5):R132.

16. Liu Y, Zhang X, Liu J, Hou G, Zhang S, Zhang J. Everolimus in combination with letrozole inhibit human breast cancer MCF-7/Aro stem cells via PI3K mTOR pathway: an experimental study. Tumour Biol. 2014;35(2):1275-86.

17. Chen X, Zhao M, Hao M, Sun X, Wang J, Mao Y, Zu L, Liu J, Shen Y, Wang J, et al. Dual Inhibition of PI3K and mTOR Mitigates Compensatory AKT Activation and Improves Tamoxifen Response in Breast Cancer. Mol Cancer Res. 2013;11(10):1269-78.

18. Jordan NJ, Dutkowski CM, Mottram HJ, Hutcheson IR, Nicholson RI, Guichard SM, Gee JM. Impact of dual mTORC1/2 mTOR kinase inhibitor AZD8055 on acquired endocrine resistance in breast cancer in vitro. Breast Cancer Res. 2014;16(1):R12. 
19. Baraz R, Cisterne A, Saunders PO, Hewson J, Thien M, Weiss J, Basnett J, Bradstock KF, Bendall LJ. mTOR inhibition by everolimus in childhood acute lymphoblastic leukemia induces caspase-independent cell death. PLoS One. 2014;9(7):e102494.

20. Santoni M, Pantano F, Amantini C, Nabissi M, Conti A, Burattini L, Zoccoli A, Berardi R, Santoni G, Tonini G, et al. Emerging strategies to overcome the resistance to current mTOR inhibitors in renal cell carcinoma. Biochim Biophys Acta. 2014;1845(2):221-31.

21. Clarke R, Shajahan AN, Riggins RB, Cho Y, Crawford A, Xuan J, Wang Y, Zwart A, Nehra R, Liu MC. Gene network signaling in hormone responsiveness modifies apoptosis and autophagy in breast cancer cells. J Steroid Biochem Mol Biol. 2009;114(1-2):8-20.

22. Crawford AC, Riggins RB, Shajahan AN, Zwart A, Clarke R. Co-inhibition of $B C L-W$ and $B C L 2$ restores antiestrogen sensitivity through BECN1 and promotes an autophagy-associated necrosis. PLoS One. 2010;5(1):e8604.

23. Weidberg H, Shvets E, Shpilka T, Shimron F, Shinder V, Elazar Z. LC3 and GATE-16/GABARAP subfamilies are both essential yet act differently in autophagosome biogenesis. EMBO J. 2010;29(11):1792-802.

24. Chiang HL, Terlecky SR, Plant CP, Dice JF. A role for a 70-kilodalton heat shock protein in lysosomal degradation of intracellular proteins. Science. 1989;246(4928):382-5.

25. Agarraberes FA, Terlecky SR, Dice JF. An intralysosomal hsp70 is required for a selective pathway of lysosomal protein degradation. J Cell Biol. 1997; 137(4):825-34

26. Dokladny K, Zuhl MN, Mandell M, Bhattacharya D, Schneider S, Deretic V, Moseley PL. Regulatory coordination between two major intracellular homeostatic systems: heat shock response and autophagy. J Biol Chem. 2013;288(21):14959-72.

27. Park MA, Yacoub A, Rahmani M, Zhang G, Hart L, Hagan MP, Calderwood SK, Sherman MY, Koumenis C, Spiegel S, et al. OSU-03012 stimulates PKRlike endoplasmic reticulum-dependent increases in 70-kDa heat shock protein expression, attenuating its lethal actions in transformed cells. Mol Pharmacol. 2008;73(4):1168-84.

28. Garrido C, Bruey JM, Fromentin A, Hammann A, Arrigo AP, Solary E. HSP27 inhibits cytochrome c-dependent activation of procaspase-9. Faseb j. 1999;13(14):2061-70.

29. Arrigo AP, Firdaus WJ, Mellier G, Moulin M, Paul C, Diaz-latoud C, Kretz-remy C. Cytotoxic effects induced by oxidative stress in cultured mammalian cells and protection provided by Hsp27 expression. Methods. 2005;35(2):126-38.

30. Chen CY, Chen HF, Gi SJ, Chi TH, Cheng CK, Hsu CF, Ma YS, Wei YH, Liu CS, Hsieh M. Decreased heat shock protein 27 expression and altered autophagy in human cells harboring A8344G mitochondrial DNA mutation. Mitochondrion. 2011;11(5):739-49.

31. Jiang SY, Wolf DM, Yingling JM, Chang C, Jordan VC. An estrogen receptor positive MCF-7 clone that is resistant to antiestrogens and estradiol. Mol Cell Endocrinol. 1992;90(1):77-86.

32. Pink JJ, Jiang SY, Fritsch M, Jordan VC. An estrogen-independent MCF-7 breast cancer cell line which contains a novel 80-kilodalton estrogen receptor-related protein. Cancer Res. 1995;55(12):2583-90.

33. Lewis JS, Meeke K, Osipo C, Ross EA, Kidawi N, Li T, Bell E, Chandel NS, Jordan VC. Intrinsic mechanism of estradiol-induced apoptosis in breast cancer cells resistant to estrogen deprivation. J Natl Cancer Inst. 2005;97(23):1746-59.

34. Lewis-Wambi JS, Kim HR, Wambi C, Patel R, Pyle JR, Klein-Szanto AJ, Jordan VC. Buthionine sulfoximine sensitizes antihormone-resistant human breast cancer cells to estrogen-induced apoptosis. Breast Cancer Res. 2008;10(6):R104.

35. Lewis JS, Jordan VC. Selective estrogen receptor modulators (SERMs): mechanisms of anticarcinogenesis and drug resistance. Mutat Res. 2005; 591(1-2):247-63.

36. Lewis-Wambi JS, Kim H, Curpan R, Grigg R, Sarker MA, Jordan VC. The selective estrogen receptor modulator bazedoxifene inhibits hormoneindependent breast cancer cell growth and down-regulates estrogen receptor alpha and cyclin D1. Mol Pharmacol. 2011;80(4):610-20.

37. Hurvitz S, Kalous O, Conklin D, Desai A, Dering J, Anderson L, O'Brien N, Kolarova T, Finn R, Linnartz $R$, et al. In vitro activity of the mTOR inhibitor everolimus, in a large panel of breast cancer cell lines and analysis for predictors of response. Breast Cancer Res Treat. 2015;149(3):669-80.

38. Leung EY, Askarian-Amiri M, Finlay GJ, Rewcastle GW, Baguley BC. Potentiation of Growth Inhibitory Responses of the mTOR Inhibitor Everolimus by Dual mTORC1/2 Inhibitors in Cultured Breast Cancer Cell Lines. PLoS ONE. 2015;10(7):e0131400.

39. Martin EC, Rhodes LV, Elliott S, Krebs AE, Nephew KP, Flemington EK, Collins-Burow BM, Burow ME. microRNA regulation of mammalian target of rapamycin expression and activity controls estrogen receptor function and RAD001 sensitivity. Mol Cancer. 2014;13:229.

40. Liu H, Zang C, Schefe JH, Schwarzlose-Schwarck S, Regierer AC, Elstner E, Schulz CO, Scholz C, Possinger K, Eucker J. The mTOR inhibitor RAD001 sensitizes tumor cells to the cytotoxic effect of carboplatin in breast cancer in vitro. Anticancer Res. 2011;31(9):2713-22.

41. Bihani T, Ezell SA, Ladd B, Grosskurth SE, Mazzola AM, Pietras M, Reimer C, Zinda M, Fawell S, D'Cruz CM. Resistance to everolimus driven by epigenetic regulation of MYC in ER+ breast cancers. Oncotarget. 2015;6(4):2407-20.

42. Lewis-Wambi JS, Cunliffe HE, Kim HR, Willis AL, Jordan VC. Overexpression of CEACAM6 promotes migration and invasion of oestrogen-deprived breast cancer cells. Eur J Cancer. 2008;44(12):1770-9.

43. Choi HJ, Lui A, Ogony J, Jan R, Sims PJ, Lewis-Wambi J. Targeting interferon response genes sensitizes aromatase inhibitor resistant breast cancer cells to estrogen-induced cell death. Breast Cancer Res. 2015;17:6.

44. Staka CM, Nicholson RI, Gee JM. Acquired resistance to oestrogen deprivation: role for growth factor signalling kinases/oestrogen receptor cross-talk revealed in new MCF-7X model. Endocr Relat Cancer. 2005;12 Suppl 1:S85-97.

45. Henriksen KL, Rasmussen BB, Lykkesfeldt AE, Moller S, Ejlertsen B, Mouridsen $H T$. An ER activity profile including ER, PR, BCl-2 and IGF-IR may have potential as selection criterion for letrozole or tamoxifen treatment of patients with advanced breast cancer. Acta Oncol. 2009:48(4):522-31.

46. Shim WS, Conaway M, Masamura S, Yue W, Wang JP, Kmar R, Santen RJ. Estradiol hypersensitivity and mitogen-activated protein kinase expression in long-term estrogen deprived human breast cancer cells in vivo. Endocrinology. 2000;141(1):396-405.

47. Chou SD, Prince T, Gong J, Calderwood SK. mTOR is essential for the proteotoxic stress response, HSF1 activation and heat shock protein synthesis. PLoS One. 2012;7(6):e39679.

48. Wang W-B, Feng L-X, Yue Q-X, Wu W-Y, Guan S-H, Jiang B-H, Yang M, Liu X, Guo D-A. Paraptosis accompanied by autophagy and apoptosis was induced by celastrol, a natural compound with influence on proteasome, ER stress and Hsp90. J Cell Physiol. 2012;227(5):2196-206.

49. Jhaveri K, Ochiana SO, Dunphy MPS, Gerecitano JF, Corben AD, Peter RI, Janjigian YY, Gomes-DaGama EM, Koren J, Modi S, et al. Heat shock protein 90 inhibitors in the treatment of cancer: current status and future directions. Expert Opin Investig Drugs. 2014;23(5):611-28.

50. Schulz R, Marchenko ND, Holembowski L, Fingerle-Rowson G, Pesic M, Zender L, Dobbelstein M, Moll UM. Inhibiting the HSP90 chaperone destabilizes macrophage migration inhibitory factor and thereby inhibits breast tumor progression. J Exp Med. 2012;209(2):275-89.

51. Whitesell $\mathrm{L}$, Lindquist $\mathrm{S}$. Inhibiting the transcription factor HSF1 as an anticancer strategy. Expert Opin Ther Targets. 2009;13(4):469-78.

52. Sidera K, Patsavoudi E. HSP90 inhibitors: current development and potential in cancer therapy. Recent Pat Anticancer Drug Discov. 2014;9(1):1-20.

53. Loehberg CR, Strissel PL, Dittrich R, Strick R, Dittmer J, Dittmer A, Fabry B, Kalender WA, Koch T, Wachter DL, et al. Akt and p53 are potential mediators of reduced mammary tumor growth by cloroquine and the $\mathrm{MTOR}$ inhibitor RAD001. Biochem Pharmacol. 2012;83(4):480-8.

54. Munoz-Gamez JA, Rodriguez-Vargas JM, Quiles-Perez R, Aguilar-Quesada R, Martin-Oliva D, de Murcia G, Menissier de Murcia J, Almendros A, Ruiz de Almodovar M, Oliver FJ. PARP-1 is involved in autophagy induced by DNA damage. Autophagy. 2009;5(1):61-74.

55. Kotoglou P, Kalaitzakis A, Vezyraki P, Tzavaras T, Michalis LK, Dantzer F, Jung $J U$, Angelidis C. Hsp70 translocates to the nuclei and nucleoli, binds to XRCC1 and PARP-1, and protects HeLa cells from single-strand DNA breaks. Cell Stress Chaperon. 2009;14(4):391-406.

56. Cai $Y$, Xia Q, Su Q, Luo R, Sun Y, Shi Y, Jiang W. mTOR inhibitor RAD001 (everolimus) induces apoptotic, not autophagic cell death, in human nasopharyngeal carcinoma cells. Int J Mol Med. 2013;31(4):904-12.

57. Rangwala R, Chang YC, Hu J, Algazy KM, Evans TL, Fecher LA, Schuchter LM, Torigian DA, Panosian JT, Troxel AB. Combined MTOR and autophagy inhibition: phase I trial of hydroxychloroquine and temsirolimus in patients with advanced solid tumors and melanoma. Autophagy. 2014;10(8):1391-402. 